\title{
Role of Mathematical Self-Efficacy and Self-Concept in Mathematics Achievement: A Structural-Motivational Model
}

\author{
Matematik Başarısında Matematik Öz-Yeterliği ve Matematik Benlik Saygısının \\ Rolü: Yaptsal-Motivasyonel Bir Model
}

\begin{abstract}
Cem Oktay GÜZELLER* Ayça AKIN**

Abstract: Mathematical self-efficacy and mathematical self-concept are motivational elements of socialcognitive theory. This theory proposes that mathematical self-efficacy and mathematical self-concept are better mediators or predictors of mathematics achievement than affective-motivational and background variables. Therefore, the aim of the research is to investigate a structural-motivational model of mathematics achievement for a low performing country in the PISA (Turkey) based on the integration of Ferla, Valcke and Cai's (2009) model of mathematical self-efficacy and self-concept for a high performing country in the PISA (Belgium). Important finds from the model indicates: (a) mathematical self-efficacy was more predictive of mathematics achievement than is mathematical self-concept, mathematics anxiety, mathematics interest, grade level, or gender, while mathematical self-concept is a better mediator for affective-motivational variables on mathematics achievement than the other variables; (b) students' mathematical self-efficacy strongly influenced their mathematical self-concept and not vice versa; (c) surprisingly, mathematics interest has a negative influence on mathematics achievement; and (d) the proposed model explained $34 \%$ of the variance in mathematics achievement. These results show the importance of academic motivation in the prediction of mathematics achievement for low performing and high performing countries in the PISA.
\end{abstract}

Keywords: Mathematical Self-Efficacy, Mathematical Self-Concept, Mathematics Anxiety, PISA

$\ddot{O}_{z:}$ Matematik öz-yeterliği ve matematik benlik saygısı sosyo-bilişsel kuramın motivasyonel bileşenlerindendir. Bu kuram matematik öz-yeterliği ve matematik benlik saygısının matematik başarısında, duyuşsal-motivasyonel ve arka plan değişkenleri üzerinde iyi bir tahminci ya da aracı olduğunu önermektedir. Bu neden ile bu çalışmanın amacı Ferla, Valcke ve Cai'nin (2009) PISA'da yüksek performanslı bir ülke (Belçika) için akademik öz-yeterlik ve benlik saygısı modeline entegre edip temel alarak PISA'da düşük performanslı (Türkiye) bir ülkenin matematik başarısının yapısal-motivasyonel modelini incelemektir. Modeldeki elde edilen önemli bulgular (a) matematik öz-yeterliğinin matematik benlik saygısı, matematik ilgisi, sınıf seviyesi ya da cinsiyete göre daha iyi bir yordayıcı olduğunu, matematik benlik saygısının ise matematik başarısı üzerindeki duyuşsal-motivasyonel değişkenler için iyi bir aracı olduğunu; (b) öğrencilerin matematik öz-yeterliği güçlü bir şekilde matematik benlik saygısını etkilediğini ve bunun tam tersinin olmadığını; (c) şaşırtıcı bir şekilde, matematik ilgisinin matematik başarısı üzerinde negatif bir etkiye sahip olduğunu; ve (d) önerilen modelin matematik başarısını 34\% varyans ile açıkladığını göstermiştir. Bulgular PISA'da düşük ve yüksek performanslı ülkelerin matematik başarısının tahmininde akademik motivasyonun önemini göstermiştir.

Anahtar sözcükler: Matematik Öz-Yeterliği, Matematik Benlik Saygısı, Matematik Kaygısı, PISA

\footnotetext{
* Doç. Dr., Akdeniz Üniversitesi, Turizm Fakültesi, Gastronomi ve Mutfak Sanatları Bölümü, Antalya. cemg@akdeniz.edu.tr

** PhD, Kastamonu Üniversitesi, Eğitim Fakültesi, Matematik ve Fen Bilimleri Eğitimi Bölümü, Kastamonu. aycaakin07@gmail.com
} 


\section{Introduction}

Educational systems pay increasing attention to international benchmarking research on students' achievement (Shin, Lee \& Kim 2009). PISA is the biggest international benchmarking research regarding students' performance in mathematics, science and reading literacy. PISA measures literacy by open-ended problems and survey including students' socio-demographic data and their motivation concerning related subjects in that application term (OECD 2005). This research is grounded in the integration of Ferla, Valcke and Cai's (2009) model of mathematical self-efficacy and self-concept. This study is grounded in an analysis of the Belgian data (i.e. a high performing country) from the PISA 2003. This research found that mathematics self-efficacy was a better predictor and mediator for mathematics achievement, whereas mathematical self-concept was a better predictor and mediator for affectivemotivational variables, and mathematical self-efficacy, mathematical self-concept empirically represents two separate constructs, although investigated within the same field.

PISA reports revealed that Belgium represents a high performing country in the context of mathematical literacy and problem solving, whereas several countries such as Turkey and Mexico represent a low performing country, regarding mathematical literacy and problem solving. The failure of Turkish students in mathematics can be related to many factors such as negative attitudes towards mathematics, mathematical beliefs, unusual questions format etc. (Güzeller \& Akın 2011). We hypothesized that Ferla et al. (2009) study, grounded in an analysis of the low performing countries (i.e. Turkey) data from the PISA 2003, that the mathematical self-efficacy and mathematical self-concepts might play out differently here (i.e. whether the similar structural-motivational model's analyses might perform well or not, to clarify the connection between mathematical self-efficacy and mathematical self-concept), and that the results obtained could be quite different. For example, TIMSS 1999 and 2007 indicated that the Turkish students' performance couldn't be predicted by the psychological structures, such as attitudes toward mathematics, mathematics anxiety and mathematics interest (Uzun, Bütüner \& Yiğit 2010). PISA results showed that the role of mathematical self-efficacy in mathematics achievement was stronger in high performing countries (e.g. Finland) than in low performing countries (e.g. Turkey) (Yıldırım 2011). Furthermore, the finds from many studies indicated that lower-achieving students performed worse than higher-achieving students (e.g. Bakers, Gersten \& Lee 2002; Owusu, Monney, Appiah \& Wilmot 2010; Shirvani 2010), that lower achievers generally had more negative attitudes towards mathematics, that they were more anxious than higher achievers (Aiken 1970), and that attitudes towards mathematics was a stronger predictor of mathematics performance for higher achievers than for the lower achievers (e.g. Güzel \& Berberoğlu 2005). Therefore, in this study, the researchers examine the factors affecting the mathematical literacy of Turkish students representing a low-performing country, using linear structural modelling.

\section{Definition of Psychological Constructs}

\section{Mathematical self-efficacy}

In psychology, self-efficacy is defined as "the belief in one's capabilities to organize and execute the courses of action required to manage prospective situations" (Bandura 1995, 2). It is highly domain-specific, task-specific and changeable (Ross 2008). For instance, a student may have high self-efficacy for algebra homework problems, but low self-efficacy for geometry homework problems. Therefore, self-efficacy theory maintains that the best predictors of behaviour in specific conditions are the individuals' perceptions inside these conditions (Schunk 1991). 


\section{Mathematical self-concept}

Self-concept is "an individual's perception of herself/himself" (Shavelson, Hubner \& Stanton 1976, 411). Mathematical self-concept is related to "perceptions of one's mathematical skill to learn and execute mathematics tasks, one's confidence in being able to learn mathematical new issues, and how interested one is in following mathematical opinions" (Reyes 1984, 560). Bong and Skaalvik (2003) characterize the difference between mathematical self-efficacy and selfconcept as follows: Self-efficacy is associated with the perceived confidence in one's own abilities and competence within a particular academic task; while self-concept is associated with the perceived appraising judgement of one's own self-regard within a given academic area. To sum up, the self-concept inclines to be past-oriented, resistant to change and stable over time while self-efficacy tends to be future-oriented, dynamic and malleable (Bong \& Skaalvik 2003; Ferla et al. 2009). Moreover, students' mathematical self-concept is both a strong predictor of student performance and an important outcome of mathematics education (Güzel 2006).

\section{Mathematics anxiety}

Mathematics anxiety that correlates with feelings of helplessness, under affective stress when asked to perform mathematics operations or problems (Schulz 2005; Gresham 2007). Students who are mathematics anxious may avoid mathematics-related activities and courses (Isiksal, Curan, Koc \& Askun 2009). Many studies (e.g. Hembree 1990; Isiksal et al. 2009) have confirmed that mathematics anxiety generally results from a lack of confidence, ineffectual teachers, poor academic achievement or bad experiences. Moreover, mathematics anxiety has a powerful influence upon mathematics education due to negatively affecting students' mathematics attitude and mathematics performance. Much research (e.g. Ferla et al. 2009; Isiksal et al. 2009) indicates that anxiety in mathematics is associated with mathematical self-efficacy and mathematical self-concept.

\section{Mathematics interest}

Mathematics interest and achievement may be mutually reinforcing and may also be affected by the students' social backgrounds (Güzel 2006), mathematical self-efficacy and self-concept. The social-cognitive career theory suggested that mathematics interest arises from student's mathematical self-efficacy and outcome expectation beliefs (Lent, Brown \& Hackett 1994). Therefore, mathematical self-efficacy was the strongest variable in predicting mathematics interest and choice intentions (Waller 2006). Students with higher mathematics interest spend more time doing maths tasks or show higher mathematics achievement than students with lower mathematics interest (e.g. Hidi 1990).

Many studies (e.g. Guzel \& Berberoglu 2005; Ferla et al. 2009; Is1ksal et al. 2009) indicate that mathematical self-efficacy and mathematical self-concept are strong predictors or mediators of mathematics achievement and affective-motivational variables (e.g. mathematics anxiety and mathematics interest), and mathematical self-efficacy and mathematical self-concept also played a key role in predicting the background (e.g. gender) and affective-motivational variables of the students. Although the result provides some guidance as to what can be anticipated in the relationship of mathematics achievement to mathematical self-efficacy, mathematical selfconcept, mathematics anxiety and interest, research is scarce. In consequence, more research is needed that has analysis of the factors affecting mathematics achievement.

\section{Methodology}

The aim of this research was to examine the hypothesized relationships of four latent variables, 
(mathematical self-efficacy, mathematical self-concept, mathematics anxiety and mathematics interest) and observed variables (gender, grade level) by using structural equation modeling (SEM), for this reason this study represents a relational research.

\section{Participants}

4855 students from Turkey participated in PISA 2003. By gender, 2090 students were females and 2755 students were males. The numbers and percentages of the Turkish participants are given in Table 1, in terms of the school-type.

Table 1. Participant Students in Terms of the School Type

\begin{tabular}{|l|c|c|}
\hline School type & Number & Percentage \\
\hline High school & 2917 & $60.1 \%$ \\
\hline Anatolian vocational high school & 727 & $15.0 \%$ \\
\hline Vocational high school & 633 & $13.0 \%$ \\
\hline Anatolian high school & 200 & $4.1 \%$ \\
\hline Private high school & 161 & $3.3 \%$ \\
\hline Middle school & 119 & $2.5 \%$ \\
\hline High school of science & 63 & $1.3 \%$ \\
\hline Police academy & 35 & $0.7 \%$ \\
\hline
\end{tabular}

\section{Instruments}

Mathematical self-efficacy (MSE). In the context of PISA 2003, mathematical self-efficacy was obtained from students' answers to 8 items (e.g. "Calculating the petrol consumption rate of a car") which was measured with a 4-point Likert-type scale (see all items in Appendix A). $(\bar{x}=2.76 \mathrm{SD}=.77, \alpha=.88)$.

Mathematical self-concept (MSC). In the context of PISA 2003, the mathematical self-concept was obtained from students' answers to 5 items (e.g. "I get good marks in mathematics") which were measured with a 4-point Likert-type scale (see all items in Appendix A) $(\bar{x}=2.48$ $\mathrm{SD}=.50, \alpha=.87)$.

Mathematics anxiety (MA). In the context of PISA 2003, mathematics anxiety was obtained from the students' answers to 5 items (e.g. "I feel helpless when doing a mathematics problem") which were measured with 4-point Likert-type scale (see all items in Appendix A). ( $\bar{x}=2.58$, $\mathrm{SD}=.69, \alpha=.81)$.

Mathematics interest (MI). The PISA 2003 index of mathematics interest was obtained from the students' answers to 4 items (e.g. "I enjoy reading about mathematics") which were measured with a 4-point Likert-type scale (see all items in Appendix A). $(\bar{x}=2.67, \mathrm{SD}=.80, \alpha=$ $.89)$.

Mathematics achievement test. Mathematical literacy was included in 85 questions of various levels of difficulty from four learning domains: algebra, numbers/operations, geometry and probability. The mathematical literacy score for Turkish participants was $423(\bar{x}=423$, $\mathrm{SD}=105$, Cronbach's $\alpha=.92$ ) (OECD 2005). Moreover, this research includes the following variables: grade level and gender. The tests and surveys of the PISA 2003 project were conducted in May 2003.

\section{Statistical Analyses}

The current analysis was performed using structural equation modelling with latent and 
observed variables. To examine the analysis of the model data fit assessment, $\chi 2 / \mathrm{df}$, GFI, AGFI, CFI and RMSEA were used to judge the fit of the model proposed (e.g. Jöreskog \& Sörbom 1993). The expected values for a good model fit interpretation are possible if the value of chisquare ratio is less than or equal to 3, the values of GFI, AGFI and CFI are greater than .90 and the value of RMSEA is smaller than .08, then the model is acceptable (e.g. Browne \& Cudeck 1993).

The structural-motivational model is "especially appropriate in a research in which the tenets of social cognitive theory and previous findings are such that hypothesized relationships have strong theoretical and empirical and theoretical support" (Pajares \& Miller 1994, 197). Therefore, the present structural model was grounded in Ferla's et al. (2009) model of academic self-efficacy and academic self-concept. In the model it was assumed that a reciprocal relationship existed between MSE and MSC, the common mechanisms (gender, prior math grade, MSE, MSC, MA and MI) were hypothesized to influence mathematics achievement directly (see Fig. 1). The statistical analyses in this study were conducted through the following steps: (i) the student questionnaire items related to each psychological construct were identified, (ii) groups of items were selected in order to constitute the latent variables for the path analytic model, (iii) latent variables were constituted via CFA, (iv) a model that involved the latent variables derived from CFA with the mathematics achievement proposed predicated on Ferla's et al. (2009) study, (v) the fit of hypothesized path analytic model was analyzed. The models tested in this research examined the impact of gender, grade level, MSE, MSC, MA and MI on mathematics achievement.

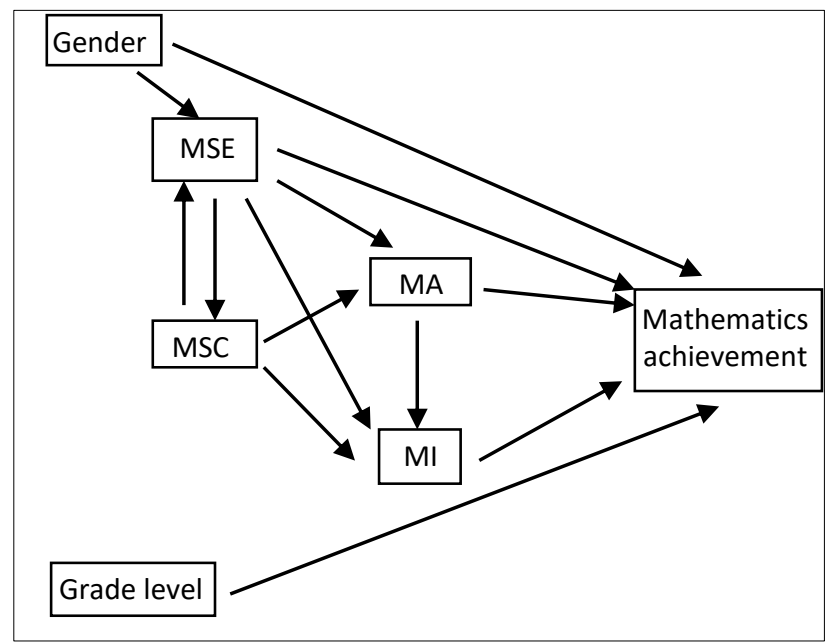

Fig. 1. The Hypothesized Structural-Motivational Model of Mathematics Achievement

indices for the four measurement models are given in Table 2

Table 2. Fit Indices for the Four Measurement Models

\begin{tabular}{|l|c|c|c|c|c|c|}
\hline Model & $\chi^{2} / d f$ & $p$ & GFI & AGFI & CFI & RMSEA \\
\hline MSE & 6.1 & .000 & .99 & .99 & 1 & .034 \\
\hline MSC & 5.3 & .000 & 1 & .99 & 1 & .046 \\
\hline MA & 5.5 & .001 & 1 & .99 & 1 & .035 \\
\hline MI & 5.9 & .002 & 1 & .99 & 1 & .041 \\
\hline
\end{tabular}

Finds from all one-factor models showed a very good fit. Even though the ratios of chi-square to degrees of freedom were higher than anticipated, all other fit indices indicated a good fit. In the 
one-factor models, all observed variables were significantly associated with their underlying latent construct $(\mathrm{p}<.00)$, the internal consistency of these scales was good $(\alpha=.88, \alpha=.87, \alpha=$ .81 and $\alpha=.89$ for MSE, MSC, MA and MI respectively) and all factor loadings were higher than .60 .

Table 3 presents the Pearson product-moment, polyserial and polychoric correlations for all variables. These results are quite interesting from this study due to the strong correlational relationships observed between mathematical self-concept and mathematical anxiety $(r=-.44$, $\mathrm{p}<.01)$, mathematical self-efficacy and math score $(\mathrm{r}=.54, \mathrm{p}<.01)$ and, mathematical selfconcept and mathematics interest $(\mathrm{r}=.61, \mathrm{p}<.01)$.

Table 3. Zero-Order, Polyserial and Polychoric Correlations for All Variables in the Research

\begin{tabular}{|c|c|c|c|c|c|c|c|}
\hline Variable & MSE & MSC & MA & MI & Gender & Grade level & Math score \\
\hline MSE & - & & & & & & \\
\hline MSC & $(\mathrm{PE})^{.38^{* *}}$ & - & & & & & \\
\hline MA & $(\mathrm{PE})^{-.32 * *}$ & $(\mathrm{PE})^{-.44 * *}$ & - & & & & \\
\hline MI & $(\mathrm{PE})^{.39 * *}$ & $(\mathrm{PE})^{.61^{* *}}$ & $(\mathrm{PE})^{-.48 * *}$ & - & & & \\
\hline Gender & $(\mathrm{PS})^{.12 * *}$ & $(\mathrm{PS})^{.10^{* *}}$ & $(\mathrm{PS})^{-.14^{* *}}$ & $(\mathrm{PS})^{.08^{* *}}$ & - & & \\
\hline Grade level & $(\mathrm{PS})^{.02 * *}$ & $(\mathrm{PS})^{.01 * *}$ & $(\mathrm{PS})^{.02 * *}$ & $(\mathrm{PS})^{-.03 * *}$ & $(\mathrm{PC})^{-.13 * *}$ & - & \\
\hline Math score & $(\mathrm{PE})^{.54 * *}$ & $(\mathrm{PE})^{.26^{* *}}$ & $(\mathrm{PE})^{-.33^{* *}}$ & $(\mathrm{PE})^{.20^{* *}}$ & $(\mathrm{PS})^{.12^{* *}}$ & $(\mathrm{PS})^{.14^{* *}}$ & - \\
\hline
\end{tabular}

** $\mathrm{p}<.01, \mathrm{PE}$ : pearson product-moment correlation, PS: polyserial correlation; PC: polychoric correlation

\section{The Structural-motivational Model}

Three structural models were assessed and compared, aiming to test hypotheses regarding background and affective-motivational variables to mathematics achievement. In model 1, it was assumed that (a) MSC affected MSE (b) mathematics achievement was influenced by the two observed variables (gender, grade level) and latent variables, (MSE, MA and MI), (c) a causal relationship existed among the four mathematical constructs (MSE and MA, MSE and MI, MSC and MA, MSC and MI, and MA and MI), and (d) the relationship existed between gender and mathematical self-efficacy. The only difference between model 2 and model 1 was that the arrow goes from MSE to MSC. Model 3 was the same as Model 2 with the addition of a direct path from MSC to MSE. We can say that the structural-motivational model 1 in which MSC is presumed to unidirectionally affect MSE, the structural-motivational model 2 in which MSE is presumed to unidirectionally affect MSC, and the structural-motivational model 3 in which MSC and MSE are presumed to affect each other reciprocally.

Model 1 did not fit the data as demonstrated by the ratios of chi-square to degrees of freedom $(\chi 2 / \mathrm{df}, 70.06 / 8=8.757, \mathrm{p}<.001)$. Other indices, for instance, the GFI, AGFI, CFI, RMSEA were found to be $.99, .98, .99$, and .043 , respectively, and they proposed reasonable fit of the model. Results indicate significant path coefficients between all variables in Model 1. The goodness-of-fit indexes for the model 2 were: $\chi 2 / \mathrm{df}(23.87 / 8)=2.98, \mathrm{GFI}=1.00, \mathrm{AGFI}=.99$, $\mathrm{CFI}=1.00$, and RMSEA $=.032$, and $\mathrm{p}<.001$. Finds for model 2 showed that all fit indices were deemed adequate to interpret the significant connections among the latent and observed 
variables. The hypothesized model (Model 3) still exhibited a lack of fit to the data, as proved by the ratios of chi-square to degrees of freedom $(\chi 2 / \mathrm{df}, 48.27 / 8=6.03, \mathrm{p}<.001)$, the goodnessof-fit indices (GFI $=.99$, AGFI $=.98$, CFI $=.97$, and RMSEA $=.039$ ), and the hypothesized model covered the non-significant path from MSC to MSE (-.19). Fig. 3 and Fig. 4 described models and informed standardized path coefficients (see Appendix B). The goodness-of-fit statistics and the model comparisons revealed that the hypothesized model (Model 3) was not superior to the alternative models (Model 1 and Model 2). Considering results of the models tested, Model 2 demonstrated the best fit and provided acceptable criteria of fit indices. Therefore, we interpreted our findings based upon Model 2 which showed that the MSE strongly influenced the MSC and not vice versa.

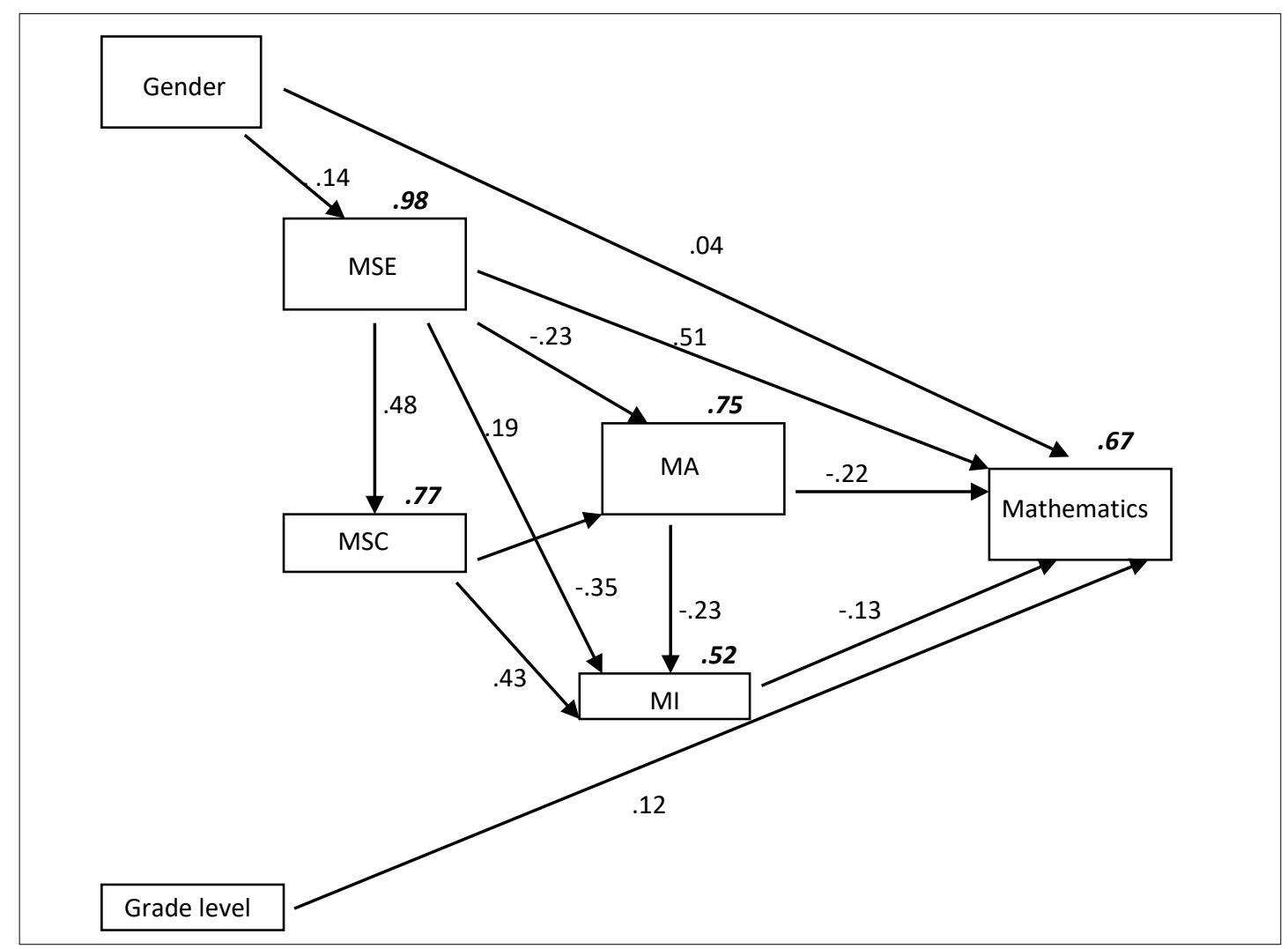

Fig. 2. The Structural-Motivational Model 2 in Which in MSE is Presumed to Unidirectionally Affect MSC

In the path model 2 (the best model), standardized coefficients were presented in Fig. 2. In this model the standardized path coefficients ranged between - .35 and .51 . According to Cohen's criteria (cited in Kline 1998), here the path coefficient from MSE to mathematics achievement indicated a large effect size (.51). The path coefficients from MSE to mathematical MSC (.48); and from MSC to MI (.43) and MA (-.35) were medium effect sizes in the model analysed. Moreover, other path coefficients indicated small effects of various magnitudes. These findings included the significant and positive effects of gender (.04), grade level (.12), and MSE (.51) on mathematics achievement. In other respects, the significant and negative effects of MI (-.13) and MA (-.22) on mathematics achievement were found in this study. The surprising findings of this research are that the strongest effects on mathematics achievement was from MSE; MSC was a better predictor/mediator for MA and MI than the other variables, and MI had a negative effect (.13) on mathematics achievement. Furthermore, the total variance explained on the mathematics 
achievement measure in the model was $34 \%$ as obtained through $\mathrm{R}^{2}$ value.

\section{Discussion}

This research investigated a structural-motivational model of mathematics achievement for a low performing country in PISA 2003 based upon the integration of Ferla's et al. (2009) model of mathematical self-efficacy and self-concept for a high performing country in the PISA. Results for a low performing country consistently supported the findings of Ferla's et al. (2009) model for a high performing country, which demonstrated that all path coefficients were significant. Several interesting finds emerged from this study.

Mathematical self-efficacy was the strongest direct predictor of mathematics achievement; as students have more mathematical self-efficacy, they demonstrate a higher performance in mathematics. This finding was in accord with previous studies (Pajares \& Miller 1994; Bong \& Skaalvik 2003 etc.) which revealed results that students' mathematical self-efficacy positively contributes to their mathematics achievement. Results showed that children's mathematical selfefficacy strongly affect their mathematical self-concept and not vice versa (see also Pajares \& Miller 1994), whereas Ferla's et al. (2009) model found that children's mathematical selfconcept beliefs affect their mathematical self-efficacy and not vice versa. For example, Pajares and Miller's (1994) study results indicated that students' mathematical self-concept was predicted by mathematical self-efficacy. They explained this situation, assuming that mathematical selfconcept might involve a mathematical self-efficacy component, and students with lower mathematical self-concept and poorer achievement was mostly owing to lower judgments of their ability (Pajares \& Miller 1994). Mathematical self-efficacy is presumably the long-term effect on mathematics achievement and mathematical self-concept, because mathematical selfefficacy assessment gives an opportunity to evaluate students' capacity to perform a specific mathematics task.

Mathematical self-concept had a medium direct effect on both mathematics anxiety (-.35) and mathematics interest (.43). As seen in the structural-motivational model, mathematical selfconcept was a better mediator for affective-motivational variables (i.e. MA and MI) on mathematics achievement than the other variables. The result is consistent with past studies (e.g. Bong \& Skaalvik 2003; Isiksal et al. 2009) which have indicated that students' mathematics self-concept strongly influences their mathematics anxiety or mathematics interest. Surprisingly, this study has shown a negative link between mathematics interest and mathematics achievement. This result of the current study is inconsistent with previous researches (e.g. Hidi 1990) which have showed a positive link between students' interest and achievement. This surprising result can be explained through two conjectures: (1) TIMSS and PISA result showed that although students from Asian countries such as Korea and Japan had outstanding mathematics achievement, students from these countries among the participant countries in TIMSS were those who disliked mathematics the most (Leung 2002). Since Asian countries (e.g. Turkey) have a collectivist culture, in these countries the community's decision and value judgements are important rather than individuals, but in European (e.g. Belgium) individualistic culture, in these countries people can decide on their own and their opinions are taken into account, their self-construct may be improved (Klassen 2004).

The patriarchal family structure is still dominant, intact and widespread throughout the Turkey (Gündüz-Kalan, 2010). The patriarchal family structure in Turkey means rule of the father in a male-dominated family, "the aging parents and one or more of their usually married male offspring live together. Unmarried children also stay in the family until they are married" 
(Elliot \& Gray 2000, 7), children cannot decide on their own, and individual's behaviour and value judgments are accepted and influenced by "society's rules of appropriate behaviour" (Müftüler-Bac 1999, 305). Considering these explanations, we can say that the Turkish family structure and the collectivist culture are similar, based upon the perspective of the children and individuals' profile features. Thus, our finding is consistent, though it is surprising, and Carmichael, Callingham, Hay and Watson's (2010) study revealed that mathematics interest exhibits a quadratic connection with mathematical self-efficacy, in that those students who have high mathematical self-efficacy are aware that they can do mathematics tasks well, and in consequence will lose attention or interest (Silvia 2003), and many studies' finds (e.g. Pajares \& Miller 1994; Güzel 2006) that recommended that students who have a high mathematical selfefficacy demonstrated higher mathematics performances than students who have a low mathematical self-efficacy and vice versa. Based upon these assumptions and finds, it could be that high-achieving students in mathematics had a high mathematical self-efficacy and they do well at mathematics task and, as a result, lose interest or were not interested in mathematical ideas. Results also indicated that students' mathematics anxiety slightly impacts upon their mathematics interest and not vice versa. Moreover, these results are in line with Bong and Skaalvik's (2003) and Ferla's et al. (2009) claims that self-concept inclines towards being stable, past-oriented and unchangeable, while self-efficacy tends towards being malleable, future-oriented and changeable. Ferla's et al. (2009) also asserts that self-concept has been mostly measured at a more general level, while self-efficacy has been mostly measured at a task-specific level.

\section{Limitations}

The present study had several limitations. In this study, we used data collected in the PISA Student Questionnaire, therefore there was nothing to be done about measures. But, if PISA employed best practice in questionnaire design, the results and relationships of the study variables could be quite different. For instance, Weng (2004) study's findings revealed that the scales which have few response types incline to the finding of lower reliability, thus the scales should be at least 5 response anchors (e.g. Weng 2004; Dillman, Smyth \& Christian 2009). We know that "strongly disagree - strongly agree" response anchors are among the worst ways to design survey items and that they are especially bad when you force respondents to "disagree" in order to agree - as is the case with "I am just not good at mathematics" (see Dillman, Smyth \& Christian 2009). This is because, respondents generally "agree" with a positively-worded item than "disagree" with it, whereas respondents "disagree" with a negatively-worded item rather than "agree" (Pearse 2011) with it. However, we think, it needs to be acknowledged that developing items for an international study is particularly difficult because in PISA all due care is taken to ensure transfer across language and culture.

\section{Conclusion}

Results from the current study supported the structural-motivational model of mathematics achievement based upon Bong and Skaalvik (2003) theoretical perspective and the integration of Ferla's et al. (2009) model. More specifically, the study indicated that mathematical selfefficacy was the strongest direct predictor of mathematics achievement, whereas mathematical self-concept is a better mediator for affective-motivational variables (MA and MI) on mathematics achievement than are the other variables. Moreover, these results are line with current empirical literature. The results of this study also confirm the predictions we have made elsewhere (e.g. Pajares \& Miller 1994) regarding the critical role that mathematical self-efficacy 
beliefs play in determining the students' mathematics achievement, and that mathematical selfconcept beliefs are a better predictor for affective-motivational variables (e.g. Isiksal et al. 2009). Interestingly, this study reveals a negative correlation between mathematics interest and mathematics achievement.

The present study was conducted to ensure a better understanding of mathematics attitudes with implications for mathematics education. Our findings highlight the importance of formulating mathematics achievement models that examine relations among mathematical selfefficacy, mathematical self-concept, mathematics anxiety, mathematics interest, gender, and grade level. One of the implications to come from our results supports the assertion that mathematics teachers should create learning environments that foster students' mathematical self-efficacy and mathematical self-concept, and highlights the significance of investigating joint relations when assessing the strength of relations among mathematics performance and self-constructs about mathematics (Yıldırım 2011). Therefore, school practitioners, researchers and teachers should be aware of their students' self-constructs about mathematics as predictors and mediators of mathematics achievement (Pajares \& Miller 1994).

Students' self-constructs about mathematics need to be assessed by their mathematics teachers in cooperation with the school counselling and guidance services which assist them in the assessment and development of students' self-constructs about mathematics, and through assessing students' self-constructs about mathematics this can ensure mathematics teachers have additional inner vision about their students' subsequent mathematics achievement (Schunk 1991). Pajares and Miller (1994) recommend that students' inaccurate perceptions of selfconstructs can give rise to students' high mathematics anxiety and avoidance of mathematics courses. Therefore, self-construct assessments should start at primary school level because there students' inaccurate perceptions of self-constructs can be recognized and changed in time (Pajares \& Miller 1994). The literature also indicated that mathematics teachers also play a key role in assessing and developing their students' self-constructs about mathematics, and learning mathematics. Thus, in-service training courses about ways of increasing the mathematical selfefficacy and mathematical self-concept can be organized for in-service and pre-service mathematics teachers (Güzel 2006). However, few people in Turkey want to be teachers. Because teachers in Turkey get poor salaries, many teachers from Turkey endure the bad working conditions such as crowded classes, limited educational investments and resources, and so they should earn money outside their schools (Aydın, Sarier \& Uysal 2012). If we want to improve Turkish students' mathematics achievement in PISA or TIMSS, both the learning environment and teaching techniques contribute to fostering mathematical self-efficacy and selfconcept of students should be planned or designed (Güzel 2006), and educational investments, resources and teachers' salaries should be increased as soon as possible (Aydin et al. 2012). Universities and the Ministry of Education can also allocate more fund or resources to assist in enhancing students' mathematical self-efficacy and mathematical self-concept (Lampert 2007). Future studies into the improvement of students' mathematics achievement should evaluate mathematical self-constructs and teacher level variables (e.g. teacher support) and the association between them using different samples such as primary schools, elementary schools, and colleges. In conclusion, these finds also provide potential insights for the conduct of future research. 


\section{Appendix A}

\section{Mathematical self-efficacy}

How confident do you feel about having to do the following mathematics tasks?

1. Using a train timetable to work out how long it would take to get from one place to another.

2. Calculating how much cheaper a TV would be after a $30 \%$ discount.

3. Calculating how many square metres of tiles you need to cover a floor.

4. Understanding graphs presented in newspapers.

5. Solving an equation like $3 x+5=17$.

6 . Finding the actual distance between two places on a map with a 1: 10,000 scale.

7. Solving an equation like $2(\mathrm{x}+3)=(\mathrm{x}+3)(\mathrm{x}-3)$.

8. Calculating the petrol consumption rate of a car.

Items are rated on a 4-point Likert scale ranging from (4) "very confident" to (1) "not at all confident".

\section{Mathematical self-concept}

Thinking about studying Mathematics: to what extent do you agree with the following statements?

1. I am just not good at Mathematics.

2. I get good marks in Mathematics.

3. I learn Mathematics quickly.

4. I have always believed that Mathematics is one of my best subjects.

5. In my Mathematics class, I understand even the most difficult work.

Items are rated on a 4-point Likert scale ranging from (4) "strongly agree" to (1) "strongly disagree".

\section{Mathematics anxiety}

Thinking about studying Mathematics: to what extent do you agree with the following statements?'

1. I often worry that it will be difficult for me in Mathematics classes.

2. I get very tense when I have to do Mathematics homework.

3. I get very nervous doing Mathematics problems.

4. I feel helpless when doing a Mathematics problem.

5. I worry that I will get poor marks in Mathematics.

Items are rated on a 4-point Likert scale ranging from (4) "strongly agree" to (1) "strongly disagree".

\section{Mathematics interest}

Thinking about your views on Mathematics: to what extent do you agree with the following statements?

1. I enjoy reading about Mathematics.

2. I look forward to my Mathematics lessons.

3. I do Mathematics because I enjoy it.

4. I am interested in the things I learn in Mathematics.

Items are rated on a 4-point Likert scale ranging from (4) "strongly agree" to (1) "strongly disagree". 


\section{Appendix B}

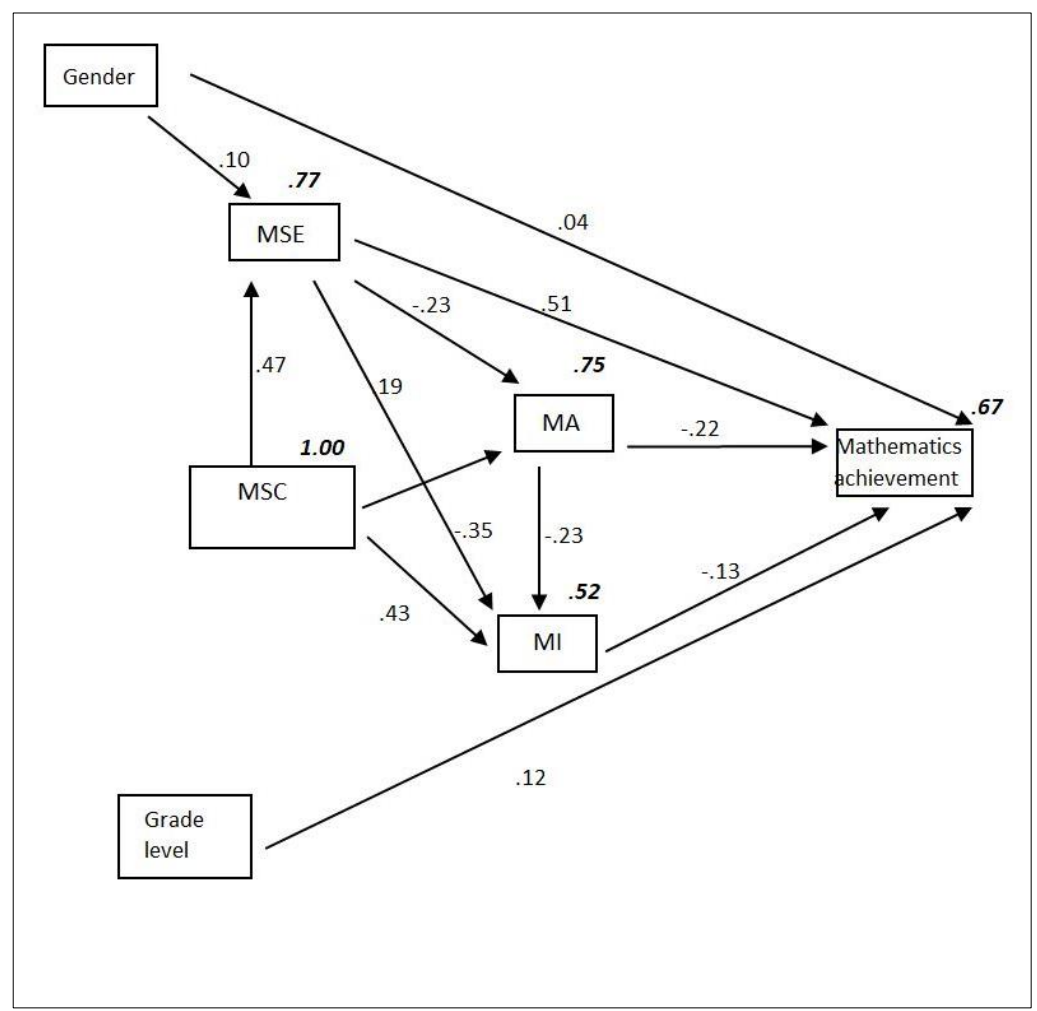

Fig. 3. The Structural-Motivational Model 1 in Which in MSC is Presumed to Unidirectionally Affect MSE

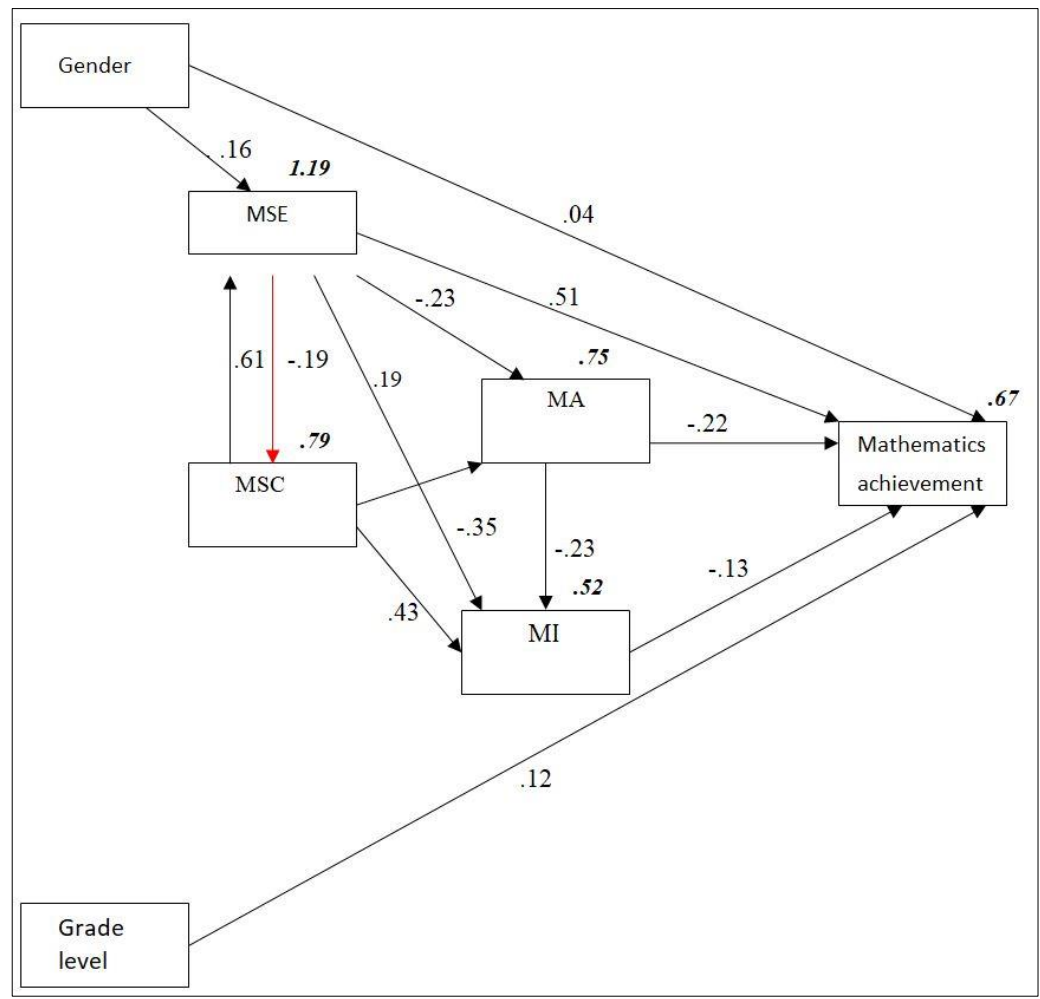

Fig. 4. The Structural-Motivational Model 3 in Which MSC and MSE are Presumed to Affect Each Other Reciprocally 


\section{KAYNAKÇA}

Aiken L. (1970) "Attitudes towards Mathematics". Review of Educational Research 40 (1970) 551-596.

Aydın A., Sarıer Y. \& Uysal Ş. (2012). "The Comparative Assessment of the Results of PISA Mathematical Literacy in Terms of Socio-Economic and Socio-Cultural Variables". Education and Science 37/164 (2012) 20-30.

Bakers S., Gersten R. \& Lee D. (2002). "A Synthesis of Empirical Research on Teaching Mathematics to Low-Achieving Students”. The Elementary School Journal 103/1 (2002) 51-73.

Bandura A. (1995). Self-Efficacy in Changing Societies. Cambridge 1995.

Bong M. \& Skaalvik E. M. (2003). "Academic Self-Concept and Self-Efficacy: How Different are They Really?” Educational Psychology Review 15 (2003) 1-40.

Carmichael C., Callingham R., Hay I. \& Watson J. (2010). "Statistical Literacy in the Middle School: The Relationship Between Interest, Self-Efficacy and Prior Mathematics Achievement". Australian Journal of Educational \& Developmental Psychology 10 (2010) 83-93.

Dillman D. A., Jolene D., Smyth J. D \& Christian L. M. (2009). Internet, Mail, And Mixed-Mode Surveys: The Tailored Design Method. New York 2009.

Elliot S. \& Gray A. (2000). Family Structures: A Report for The New Zealand Immigration Service. Immigration Research Programme. Wellington 2000.

Ferla, J. Valcke M. \& Cai Y. (2009). "Academic Self-Efficacy and Academic Self-Concept: Reconsidering Structural Relationships". Learning and Individual Differences 19/4 (2009) 499-505.

Gresham G. (2007). "A Study of Mathematics Anxiety in Pre-Service Teachers". Early Childhood Education Journal 35/2 (2007) 181-188.

Gündüz-Kalan Ö. (2011). "Media Literacy and Pre-school Children: A Research of Media Literacy Awareness". İstanbul University Faculty of Communication Journal 39 (2011) 59-73.

Güzel Ç. (2006). Cross-Cultural Comparison of Impact of Human and Physical Resource Allocations on Students' Mathematical Literacy Skills in the Programme For International Student Assessment PISA (2003). Unpublished Dissertation. Middle East Technical University, Ankara 2006.

Güzel Ç. \& Berberoğlu, G. (2005). "An Analysis of the Programme for International Student Assessment 2000 (PISA 2000) Mathematical Literacy Data for Brazilian, Japanese and Norwegian Students". Studies in Educational Evaluation 31 (2005) 283-314.

Güzeller C. O. \& Akın A. (2011). "An Examination of the Programme for International Student Assessment (PISA) 2003 Turkish Database with the Aim of Exploring the Relationship Between Homework Variables and Mathematics Achievement". Educational Research and Reviews 6/13 (2011) 793-803.

Hembree R. (1990). “The Nature, Effects, And Relief of Mathematics Anxiety”. Journal for Research in Mathematics Education 21 (1990) 33-46.

Hidi S. (1990). "Interest and Its Contribution as A Mental Resource for Learning". Review of Educational Research 60 (1990) 49-571.

Isiksal M. Curran J. M. Koc Y. \& Askun C. S. (2009). "Mathematics Anxiety and Mathematical SelfConcept: Considerations in Preparing Elementary-School Teachers". Social Behavior and Personality $37 / 5$ (2009) 631-644.

Jöreskog K. G. \& Sörbom D. (1993). LISREL 8 User's Reference Guide. Chicago 1993.

Klassen R. M. (2004). "Optimism and Realism: A Review of Self-Efficacy from A Cross-cultural Perspective". International Journal of Psychology 39/3 (2004) 205-230.

Kline R. B. (1998). Principles and Practice of Structural Equation Modeling. New York 1998.

Lampert J. N. (2007). The Relationship of Self-Efficacy and Self-concept to Academic Performance in A College Sample: Testing Competing Models and Measures. Unpublished MS. Thesis. Pacific University, Oregon 2007.

Lent R. W., Brown S. D. \& Hackett G. (1994). "Toward A Unified Social Cognitive Theory of Career/Academic Interest, Choice, and Performance". Journal of Vocational Behavior 45 (1994) 79122 . 
Leung F. K. S. (2002). "Behind the High Achievement of East Asian Students". Educational Research and Evalution 8/1 (2002) 87-108.

Marsh H. W., Trautwein U., Lüdtke O., Köller O. \& Baumert J. (2005). "Academic Self-concept, Interest, Grades, and Standardized Test Scores: Reciprocal Effects Models of Causal Ordering". Child Development 76 (2005) 397-416.

Müftüler-Bac M. (1999). “Turkish Women's Predicament”. Women's Studies International Forum 22/3 (1999) 303-15.

Organisation for Economic Co-operation and Development. (2005). PISA 2003 Technical Report. Paris 2005.

Owusu K. A. Monney K. A., Appiah J. Y. \& Wilmot E. M. (2010). "Effects of Computer-Assisted Instruction on Performance of Senior High School Biology Students in Ghana". Computer \& Education 55 (2010) 904-910.

Pajares F. \& Miller M. D. (1994). "Role of Self-Efficacy and Self-Concept Beliefs in Mathematical Problem-Solving: A Path Analysis". Contemporary Educational Psychology 20 (1994) 426-443.

Pearse N. (2011). "Deciding on The Scale Granularity of Response Categories of Likert Type Scales: The Case of a 21-Point Scale”. Electronic Journal of Business Research Methods 9/2 (2011) 159-171.

Reyes L. H. (1984). "Affective Variables and Mathematics Education". The Elementary School Journal $84 / 5$ (1984) 558-581.

Ross S. (2008). Motivation Correlates of Academic Achievement: Exploring How Motivation Influences Academic Achievement in the PISA 2003 Dataset. Unpublished Dissertation. University of Victoria, British Columbia, Canada 2008.

Schunk H. D. (1991). "Self-efficacy and Academic Motivation”. Educational Psychologist 26 (1991) 207-231.

Shavelson R. J., Hubner J. J. \& Stanton G. C. (1976). "Self-Concept: Validation of Construct Interpretations". Review of Educational Research 46 (1976) 407-441.

Shin J., Lee H. \& Kim Y. (2009). "Student and School Factors Affecting Mathematics Achievement: International Comparisons Between Korea, Japan and the USA". School of Psychology International 30 (2009) 520-537.

Shirvani H. (2010). "The Effects of Using Computer Technology with Lower-Performing Students: Technology and Student Mathematics Achievement". International Journal of Learning 17/1 (2010) 143-154.

Siegel R. G., Galassi J. P. \& Ware W. B. (1985). "A Comparison of Two Models for Predicting Mathematics Performance: Social Learning Versus Math Aptitude-Anxiety". Journal of Counseling Psychology 32 (1985) 531-538.

Silvia P. J. (2003). "Self-Efficacy and Interest: Experimental Studies of Optimal Incompetence". Journal of Vocational Behavior 62/4 (2003) 237-249.

Şahinkayası Y. (2008). A Cross-Cultural Comparison Modeling of Information and Communication Technologies Aspects Affecting Mathematical and Problem-Solving Literacy and Perceptions of Policy Makers. Unpublished Dissertation. Orta Doğu Teknik University, Ankara 2008.

Uzun S., Bütüner S. Ö. \& Yiğit N. (2010). "A Comparison of the Results of TIMSS 1999-2007: The Most Successful Five Countries-Turkey Sample”. Elementary Education Online 9/3 (2010)1174-1188.

Waller B. (2006). "Math Interest and Choice Intentions of Non-traditional African-American College Students". Journal of Vocational Behavior 68 (2006) 538-547.

Weng L. J. (2004). "Impact of the Number of Response Categories and Anchor Labels on Coefficient Alpha and Test-retest Reliability”. Educational and Psychological Measurement 64 (2004) 956-972.

Ylldırım S. (2011). "Self-Efficacy, Intrinsic Motivation, Anxiety and Mathematics Achievement: Findings from Turkey, Japan And Finland". Necatibey Fac. of Education Electronic Journal of Science and Mathematics Education 5/1 (2011) 277-291. 